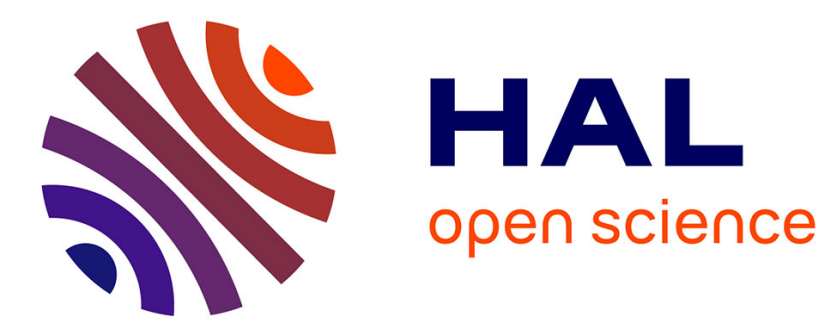

\title{
AIDS AND CIVIL SOCIETY IN TAIWAN
}

Evelyne Micollier

\section{To cite this version:}

Evelyne Micollier. AIDS AND CIVIL SOCIETY IN TAIWAN. Evelyne Micollier. Sexual Cultures in East Asia. The social construction of sexuality and sexual risk in a Time of AIDS, Routledge-Curzon Press, pp.223-240, 2004, Asian Studies. halshs-01070606

\section{HAL Id: halshs-01070606 https://shs.hal.science/halshs-01070606}

Submitted on 15 May 2017

HAL is a multi-disciplinary open access archive for the deposit and dissemination of scientific research documents, whether they are published or not. The documents may come from teaching and research institutions in France or abroad, or from public or private research centers.
L'archive ouverte pluridisciplinaire HAL, est destinée au dépôt et à la diffusion de documents scientifiques de niveau recherche, publiés ou non, émanant des établissements d'enseignement et de recherche français ou étrangers, des laboratoires publics ou privés. 


\title{
Chapter 9 AIDS ANd Civil Society IN TAIWAN ${ }^{1}$
}

\author{
EVELYNE MiCOLLIER, IRD UMI 233, INSERM U1175 \\ Cluster Local Cultures and Global Health
}

In relation to economic growth and political liberalization, the emergence of a civil society is one of the most significant social transformations, which has taken place in Taiwan since the 1980s. The development of the non- profit sector has embarked on a new and unprecedented phase. This process is a dynamic component of social change and offers an interesting perspective on the emergence of a 'civil society', a concept sure to trigger off debate among scholars when applied to Chinese and/or Taiwanese contexts (Huang 1993; Ma 1994). While the legal framework and historical background of civic bodies are both highly relevant to law and political science, studying the working methods of these organizations in daily life, human relationships, team building and networking at a micro-social scale is highly consistent with an anthropological approach. Social organizations have the capacity to access those margins of society government bodies cannot easily reach. This process allows the state to delegate the management of politically sensitive social issues. Although the government has been slow to act in launching a national offensive, a modern AIDS campaign has gradually taken shape with the help of the non-profit sector - secular and religious organizations ${ }^{2}-$ working in conjunction with official bodies.

I have done ethnographic fieldwork in Taipei. For that purpose, official bodies as well as social organizations involved in AIDS prevention and care, were approached. ${ }^{3}$ I visited regularly the service in charge of PWA/HIVs (People living with AIDS/HIV) in the Taipei hospitals appointed by the government, and worked with two secular social organizations involved in the fight against AIDS. This approach enables me to be a participant- observer, to know and interview activists from diverse social categories, social workers, journalists showing an interest in AIDS-related issues, people suffering from HIV/AIDS, health personnel in medical institutions and in officials working in health bureaus or in the headquarters of the DoH. The following topics will be discussed in this paper: The emergence of a civil society is investigated through an analysis of the development of the non-profit sector and the working methods of local NGOs. Specific questions related to the HIV/AIDS epidemic, a sensitive health issue, 
have shed an original light on the debate about civil society: official responses echo nonofficial organized responses to the epidemic threat. Finally, AIDS memorial rituals are described as voices of society, and the controversial issue of sex education is introduced.

\section{The EMERGENCE OF A Civil Society}

In contrast to the kinship group, civil society is part of the political community. Representative of progressive forces which cannot deploy themselves within the framework of a backward state which has a monopoly on social change and political power, it organizes itself as the opposition to the State. ${ }^{4}$ Considering the Chinese context, Hsu (1994) has selected the word 'society' rather than 'civil society', arguing that a citystate organization has never existed in China, and that the notion of civil society is primarily related to the social reality of Greek and Roman antiquity. Indeed, the concept of the 'public sphere' borrowed from Habermas (1989) is to be preferred when applied to Chinese culture (Huang 1993, cited by Kwok 1994). The growing role of the non-profit sector and the development of a civic culture are among the preliminary conditions for the emergence of a democracy (Wachman 1994:35).

In the early 1980s, progressive forces found themselves gathered together in a political organization 'Outside the Party' (Dangwai): Taiwan was ruled under a regime of martial law by the 'Nationalist Party' (Guomin dang). Political pluralism only came into effect in 1986 with the foundation of the 'Progressive Democratic Party' (Minjin dang) and was consolidated in 1987 with the lifting of martial law. This process of political transformation allowed progressive forces to diversify, reshaping themselves into non-political social organizations. For a decade now, civic associations have been taking various forms, diverging in both methods of working and the social purposes, which they espouse. During the 1980s, civic freedom was gradually insinuated. In this process, religious freedom was even encouraged by the nationalist government, which saw it as a remedy against the on-going erosion of traditional values and morality (Vermander 1995:11). Debate about long-tabooed matters is nowadays allowed and self- censorious behaviour is steadily being abandoned. Cultural, ethnic and linguistic plurality in Taiwan is now clearly taken for granted by people from every ring of the whole social spectrum.

The role of tensions arising from identity in the process of democratization is well documented (Wachman 1994; Geoffroy 1997). Lay associations, which are neither centred on the kinship group, nor on corporate networks or on locality or on proximity, reveal non-traditional forms. 
Collaboration involving Taiwanese and foreign NGOs, religious groups which do not share religious affiliation - Christian and Buddhist groups - in the field of public health and education is now the order of the day. This seems very upbeat but there is a downside. Many local NGOs rely on one person, or at best a few persons and never on the whole team. Without these charismatic people at the helm, the NGO is drained of efficiency either by lack of funds or a shortage of human resources. Motives for joining are generally linked to the personality or status of a president rather than to a genuine involvement in a cause. Civil society may remain weak if some actors are not intimately drawn to cause by either beliefs or practices. As Cabestan (1999:120) put it, many people are unable to accept the restrictions imposed by an organized action, which is not linked to their own immediate interests. This tendency may contribute to the slowing down of the maturing process of Taiwanese civil society. However, this feature may not be culturally bound as Cabestan suggests. Numerous changes have taken place in Taiwan during the 1990s, and they clearly show a diversification of society and social dynamics, which may be interpreted as phenomena part of a broader 'globalizing' process: this trend suggests that Taiwanese society is entering in the 'post-modernist' era described in capitalist societies of the Western world. It is thus difficult to recognize a general conservative or progressive trend.

The non-profit sector can be divided into two categories: non- governmental organizations (NGOs) (minjian tuanti) and endowment- centred foundations (jijinghui). By 1997, the number of Taiwanese NGOs including all types of political organizations had reached 12000, a 50 per cent rise compared to the early 1990s. Membership figures are high: one Taiwanese out of five is an NGO member. More than 60 per cent of the current total number of registered NGOs have been created either in the 1980s or in the 1990s. Social service oriented, public interest, and charitable organizations account for 30 per cent, while academically, culturally and internationally aligned bodies make up more than 40 per cent. According to Hsiao (1995:239), although related, two social changes regarding NGOs in Taiwan are yet distinguishable: 'One is the rise of a social movement sector within the NGOs, the other the self-transformation of many already wellestablished NGOs.' Emerging social movements urging social reforms and changes in state policies can be classified into four categories in terms of their objects of concern:

- Consumer protection, pollution, rising housing costs, and conservation - The rights of disadvantaged or stigmatized social groups such as ethnic minorities (language rights, land control, and cultural identity), the elderly, the handicapped, veterans, and certain religious groups. 
- The state's corporatist mode of control over key social groups, such as workers, farmers, students, women, teachers, and intellectuals.

- Politically sensitive issues such as the relations between Taiwanese and Mainland Chinese people, and human rights.

More than one hundred specific individual social movement organizations can be identified in terms of their objectives, social bases, and mobilization strategies. Most of them are grassroots and locally based, thus constituting the 'new sector' of Taiwan's NGOs (Hsiao 1995:240).

In 1997, there were 1600 foundations, which could be defined into three categories: most of them (70 per cent) are private and independent, 25 per cent are corporate, and 5 per cent are semi-governmental or governmental. ${ }^{5}$ Recently created non-governmental foundations dominate the sector. The increasing number of corporate foundations shows the growing interest of the private business sector in social issues. Following the same patterns as NGOs, welfare and charitable foundations constitute top-ranking categories in terms of numbers. Research, education, culture, foreign exchanges, and social involvement comprise the other high-ranking categories. Most of the foundations are operative rather than grant-giving organizations. This original feature suggests that foundations are not clearly differentiated from NGOs except in legal terms. The famous Buddhist foundation Ciji, is the most significant private foundation in terms of endowment and lay support. On the strength of its four million members, the organization is involved in social services related to education, health, and culture, not only in Taiwan but also in countries afflicted by human or natural disasters. The success of Ciji may be traced to the rise of a new conservatism (Laliberte 1998). The organization refers to some basic values of Taiwan's cultural matrix: 'It has succeeded because it appeals both to "timeless" Chinese/Taiwanese values yet also quick to adopt new forms of group organization and models of "love" familiar to lay membership as it has changed over time.' (De Vido 2001:94) For instance, Ciji 'promotes and reproduces an essentialist notion of feminine nature, of female as synonymous with Mother, as a self- sacrificing, infinitely forbearing, compassionate nurturer of others: the uncontested norm in Taiwan society' (De Vido 2001:95).

Indeed, religious organizations benefit the most from people's donations. Taiwanese attitudes towards philanthropy tend to favour traditional forms to more progressive secular forms of social solidarity. Such support of the Taiwanese public opinion for selected social organizations is one of the conservative elements remaining in a definitely emerging pluralistic society. Critical analysis of society by academics and heated debates in academic circles, the vitality of the literary scene, and the activism of the queer and

225

homosexual movements (kuer yundong, tongzhi yundong) demonstrate simultaneously the 
strength of progressive elements.

\section{RESPONSES TO THE HIV/AIDS EPIDEMIC}

The first case of HIV infection was reported in 1984 by the DoH 'Department of Health' weisheng shu, the highest governmental health body. From December 1984 to March 2000, almost 22 million blood samples were tested. The epidemiological data released in December 2000 by the DoH were as follows: the official figure shows one of the lowest infection rates in the region with 2773 'People infected with HIV' (PWH) including 905 full blown AIDS people 'People with AIDS' (PWA). More than 90 per cent of them are Taiwanese male nationals. ${ }^{6}$ The main channel of transmission is sexual ( 85 per cent of $\mathrm{PWH}$ ), more precisely heterosexual (41 per cent), bisexual (16 per cent), gay male ( 28 per cent). Bisexuality is not clearly defined. According to my ethnographic data, people included in the category are often married men, fathers, and homosexuals in their behaviour and attitudes. Looking at the problem from the perspective of age, people ranging from twenty to thirty-nine constitute 70 per cent of officially declared PWH. Turning to social indicators, it is worth noticing that 22 per cent of HIV infected people pertain to the social category 'unemployed' even though the unemployment rate ( 3 per cent in 2000) is fairly low in Taiwan. One very specific epidemic trend is the ratio male/female among reported HIV infected people, which is twelve men to one woman (women accounting for only 7.7 per cent of reported HIV infections). This figure is indeed surprising, knowing that the main epidemic channel is heterosexual transmission and that women are more vulnerable to HIV infection than men. Data show that sexual transmission is the most common infection route suggesting that AIDS control policies should focus on prevention. For that purpose, sex education programmes are gradually being introduced in schools.

The sex industry is expanding and commercial sex work is facilitating the spread of HIV infection: estimates give a figure of more than 50,000 prostitutes working in Taipei alone (The Echoes of the ROC, Sept. 21, 1997). Another risk factor is an increasing mobility of the population. The Taiwanese are quite well off on a regional scale; they have plenty of opportunities to travel both inside and outside the country either for business or tourism. Since 1989, an increasing number of migrant workers have been arriving each year from Southeast Asia (Philippines, Thailand, Indonesia) to work legally in Taiwan for a maximum of three years (Chang 1999: 14). In 2000, 310000 were officially registered. ${ }^{7}$

AIDS care is not neglected. Treatments for PWH are available, commonly accessible, and established from therapeutic trials. Testing and treatment sites are of good quality. 
Compared to Thailand for instance, the infrastructure for AIDS prevention and care, is better set up. As far as access to recent poly-therapies is concerned, the Taiwan case is unique in Asia, being one of the few countries in the world where treatment is free of charge for the patients as long as they are covered by the National Health Insurance (covering 96 per cent of the population in 1997). ${ }^{8}$

Since 1992, NGOs and volunteer groups supported by the DoH have launched an AIDS campaign, and have developed help and care networks. Their activities include organizing cultural events, conferences, sex education training, running hotlines, websites, developing sex education programmes and insinuating educational messages through the media in the press and on TV, in leaflets, brochures, and the like. Starting from 1997 and following a ten-year plan, the $\mathrm{DoH}$ is modernizing the system for controlling communicable diseases including AIDS. ${ }^{9}$ In AIDS control, the main focus is the introduction of new therapies and the launching of more efficient educational programmes for prevention.

Although epidemiological data are less alarming than in other Asian countries, by 1998, the spread of the virus had accelerated up to one new reported HIV-infection per day. ${ }^{10}$ Because of its exceptional political situation (Taiwan is not a member of the UN), the island manages to control the epidemic risk with more independence than other states, which are curbed by their rights and obligations to the UN. Despite its position as an outsider, Taiwan tends to act along the lines of UN recommendations for obvious health reasons and also for diplomatic motives. National responses are part of the state planning structure, which has addressed private and public sectors, civic collaboration, and schools. Official and non-official organized responses have to be matched. People at risk cannot be educated, informed, tested, and receive care in a context in which a mixture of silence, fear and stigmatization is the most common attitude towards the illness and towards people infected by the virus. From this perspective, sexual risk has to be clearly contextualized in order to make 'culturally appropriate interventions' (Brummelhuis and Herdt 1995:15). In Taiwan, three categories of the population are primarily involved in AIDS prevention: HIV-infected people, politicians, and health workers. HIV-infected people could organize themselves and claim their rights. Conscious of voters, politicians do not dare to lead the campaign. The awareness of health workers still has to be raised as recent studies have shown, assessing the attitude of fear and ignorance prevailing among health personnel (Yuan et al. 1994; Ting and Twu 1997).

The DoH has designed a number of policies designed to control the epidemic. The Department co-operates with other official bodies as the Ministry of Education (Jiaoyu 
$b u$ ) and the Ministry of Defence (Guofang bu), and with local NGOs. In principle, involvement in the official AIDS campaign is required from all administrative levels. Non-official organized responses to the epidemic are complementary and are indispensable to improving efficiency of institutional responses. It is important to note that only three associations are exclusively involved in the fight against AIDS: the 'Light of Friendship for AIDS Prevention and Control' (Yiguang aizi fangzhi xiehui); the 'National Association for AIDS Control' (Zhonghua minguo aizibing fangzhi xiehui); and the 'Hope workshop' (Xiwang gongzuofang). Membership, the goals and the working methods of these organizations will be examined in more detail below.

The 'Light of Friendship for AIDS Prevention and Control' (Yiguang xiehui) is an NGO funded mainly by the DoH. Numbering about 200 members, the association was created in 1992. In 1995, it split up into two on the basis of divergent standpoints on priority actions. The services provided by the Yiguang are focused more on providing information and education for AIDS prevention. The association has no links with other Taiwanese or foreign organizations. It is interesting to note that the president is head of the Taipei Health Bureau (Taipeishi weishengju). Based in Taipei, the Yiguang has also a small branch in Taizhong, the third Taiwanese city. The staff includes two social workers and three volunteers in Taipei and only one social worker in Taizhong. Documents including books, periodicals, audio- or videotapes, and the organization own publication (a monthly periodical) are freely available to the public during the regular working hours every week. A website (www.lofaa.org.tw) and a hotline are also run by the Yiguang. Educational training, informing through media and publications, free condom distribution in public places (such as main railways station, bars, and night clubs) are its main activities. Information and education may specifically target vulnerable groups such as homosexuals and commercial sex workers (CSWs). Other services such as free anonymous HIV tests, island-wide HIV/AIDS prevention and education activities, the internet as a channel for prevention and education, various training, and global interaction involving GOs and NGOs are newly available. Further information on the Yiguang can be found on its website.

The 'National Association for AIDS Control' (Zhonghua minguo aizibing fangzhi xiehui), is more medically oriented as most members are health workers and providing help and care for the patients, are its main activities. However, prevention, including some educational training in schools is also one of its undertakings. The monthly periodical published by the association is designed mainly for medical personnel. Member staff includes 
physicians, nurses, and volunteers. The main office is in Taipei with a branch in Gaoxiong, the second city of Taiwan and the biggest harbour of the island. A monthly periodical 'AIDS Prevention and Care' (Aizibing fangzhi jikan) published by the association is distributed to members, and to individual subscribers and institutions such as libraries, medical schools, institutes of public health, and healthcare services. The president, a physician and professor who is also involved in the social sciences, is chief of the 'Clinical Virology Division' of Taipei Veterans General Hospital. He gives educational training to military trainees, students, and Southeast Asian migrant workers at worksites. A hotline is available for advice and information.

The 'Hope Workshop' (Xiwang gongzuofang) operates within the framework of the 'National Academic Society for Preventive Medicine' (Zhonghua minguo yufang yixue xuehui), an academic association which covers a whole range of health workers, researchers, and professors specialized in public health or other medical disciplines. The Society is involved in all priority health issues such as early testing for cancer, antitobacco campaigns, and prevention of communicable diseases including STDs and HIV/AIDS. The 'Hope Workshop' is the main organizer of the December 1st World AIDS Day annual campaign in Taipei. In its efforts to coordinate World AIDS Day activities, the association is supported financially by the DoH and the 'National Academic Society for Preventive Medicine'. Since December 1995, World AIDS Day has been celebrated in Taiwan by stressing AIDS prevention through information and education, and by condom promotion.

Another association, the 'ROC Association for HIV/AIDS patients Rights Advocacy', is striving for legal changes in the status and rights of HIV-infected people. The aim is to obtain appropriate medical services for HIV positive patients and the right for them to continue working. The association is fighting for the right of HIV positive patients to be awarded an allowance as disabled people such as the right recognized in France. Patients in Taiwan do not yet benefit from such an allowance. Cogently, its secretary is a former staff member of the 'Hope Workshop' and that the two associations organize joint activities.

The 'Hope Workshop' did try to create a 'mid-way house', which did not work out in the wake of strong local opposition against the project. Enjoying the advantage of owning a house and for that reason, having more chance to succeed, a Roman Catholic group attempts to launch the project again. When I interviewed the head of the 'Communicable Disease Control Division', she explained the current problems related to the 'mid-way house project': 'The DoH was supporting the project in spite of obstacles: but firstly, difficulties were raised by neighbours who complained about falling local 
housing prices; secondly, this housing system is not very appropriate to the Chinese and/or Taiwanese cultural contexts. Only a few HIV-infected people need this type of housing. The DoH encourages patients to be helped in the traditional family context as for any other illness'.

Indeed, the family plays a major role in patient care: traditional conceptions of illness assume that, if a family member is ill, all the family is in fact affected. The family supports and provides care to the patient as the principal aim is to restore family harmony as soon as possible. In Taiwan, health policies are still partly drawn from traditional practices and ideas. Health care is still currently provided by the female members of the family - mothers, spouses, sisters, daughters-in-law - instead of nurses as it is the case in all modern Westernized health care systems. Nursing training was introduced quite recently into the educational system (1935) (Lu 1990:31). The first missionary nurse had arrived in China in 1884. Although China has an old medical history, professional nursing dates back only to the nineteenth century when modern Western medicine was introduced by Christian missionaries.

According to $\mathrm{Su}$ Yi-Hung, chief nurse at the Taipei Veterans General Hospital, most AIDS patients are helped and supported by their family. Informed by her thirteen-year experience of working with AIDS patients (about one hundred), she claims that 90 per cent of the families are ready to support HIV infected relatives, men tending to keep their distance and be less involved than women (The Echoes of the ROC March 1999). Published in an official news periodical, this figure may be greatly overestimated, a fact found our ethnographic data tends to support: most HIV-infected people do not inform their relatives about their HIV status when the infection is a- symptomatic. On the basis of regular visits to a Taipei hospital in services designed for AIDS patients, I have noticed that even in the case of hospitalization, only a limited number of family members visit AIDS patients.

\section{AIDS MeMORIALs AS VoICES OF SOCIETY ${ }^{11}$}

International AIDS memorial ceremonies, such as the 'Quilt Ceremony' and the 'Candlelight AIDS Memorial', have been born in the wake of the abrupt disappearance of so many young people and the distress following the disastrous consequences of the epidemic. They are part of the so-called 'new rituals' aimed at mourning and commemorating people who have died of AIDS; they are definitely performed on an international scale on World AIDS Day (1 December) but take specific cultural forms. These rituals show an aspect of social change related to AIDS (Ethnologie française 1998). 
They are now currently celebrated in Taiwan, and the specificities of these rituals in the Taiwanese cultural context give clues to hear some voices in society, which usually remain silent.

Since 1995, a Taiwanese Quilt has been conceived in co-operation with the international NGO 'Names Project' created in California in 1987 and is shown in various Taiwanese cities for World AIDS Day (Chang et al. 1997). The Quilt ceremony has two levels of significance - individual and activist: each patch, each name pronounced while the patchwork is shown, underline the uniqueness of each deceased person; the patchwork configuration, the fact that the association will collect the individual patches, put them together and show them to the world to stress the disastrous consequences of the epidemic, bring about the social significance of death due to AIDS (Fellous 1998:80). The Quilt's unique feature is that the personal mourning healing process and the collective activist campaign are closely interwoven. Interestingly, the text in Taiwanese patchworks is often written in English. Moreover, angels and crosses, both Christian symbols, are used to talk about death and to commemorate the dead. Is it a way of 'Othering' the disease, stressing its foreign nature through an imagery obviously related to Western culture? The imputation of the AIDS disease on the Other is now well documented in a number of cultures. ${ }^{12}$ For instance, in Japan, an infected and infecting mother is no longer addressed in Japanese but in English. Her body has become foreign (Buckley 1997:290). However, we need to be careful in our interpretation: local culture changes the meaning of foreign symbols, which lose their exogenous nature in the process. Moreover, the fact that Christian groups are involved in the AIDS campaign and could insinuate such meaningful images for their own purposes has to be acknowledged.

Love and sexuality from the West are referred to with the juxtaposed evocation of sexual liberation and Christian universal love. The English language and Christian symbols are commonly used in the educational messages of the AIDS campaign. The repetitive figuring of the cross in the Quilt to symbolize death, of angels and children in 'The Book of Silent Love' (Zhi et al. 1997), an educational book about safe sex published by the 'Chinese Society of Preventive Medicine', show the current need to refer to a foreign culture in order to talk about love and sex, the need for a 'screen discourse' imbued with a mediator role.

The Taiwanese 'Candlelight AIDS Memorial' called, fangshui deng, literally 'throw the lanterns in the water', commemorates the death of PWA and addresses a prayer of hope for PWH. ${ }^{13}$ Organized in Taiwan since 1994, this ritual gathers patients, relatives, and activists. Some people hide their HIV status and only a few family members attend the 
ceremony. The public and journalists were not admitted in 1997 as HIV-infected people were

worried about being identified and discriminated against. In 1999, this censoriousness of social stigmatization seemed to have improved. Indeed, journalists have been allowed to report and take photographs. ${ }^{14} \mathrm{~A}$ short article about the event with a picture, has been published in the official Echoes of the R.O.C. (Dec. 11, 1999: 4).

The lotus flower shaped lanterns, a traditional appurtenance in Buddhist death rituals, were thrown one by one into the river at dusk by each participant. Participants watched over them as they floated in the water from the starting point of their journey, and were busy putting them into the flow again if the journey was impeded by any obstacle. These ritual sequences may be an efficacious measure as they assume a structural role. White is the traditional colour of death in China: lanterns are therefore white for the dead and pink for the PWH, symbolizing hope.

PWH or volunteers involved in the fight against AIDS may interpret death from AIDS as an unnatural premature death. Moving this death away from the living people is therefore necessary. The function of the ritual is then to prevent the dead, who might come back as 'wandering souls', from harming the living. These ideas are rooted in popular religion or more precisely in popular Buddhism, which is fully integrated into popular religion. It is important to distinguish two a priori contradictory sets of ideas for a better understanding of the distinctive meaning of these ritual practices:

- On one hand, the ritual commemorates the deaths of PWA. As an international and activist memorial, one of its goals is to raise public awareness about AIDS and to show the reality of the human distress of people suffering from AIDS. Indeed, PWH live under the threat of biological death as well as of social and symbolic death, stemming from the stigmatizing attitude and behaviour of the people around them.

- On the other hand, if the ritual is related to a death traditionally perceived as unnatural and premature, PWH and activists are taking upon themselves the shame spread on family members and relatives. This death is perceived as harmful and inauspicious to the group. The ritual is then a means to escape from this 'nonominous death', to restore family and social harmony. If this interpretation of the ritual is valid, participants and initiators of the memorial ceremony may be embedded in traditional cultural representations. This ritual may then reveal a world view in transition (moving through a continuum with polarities-a 
traditional worldview and a globalizing one) in these groups of activists fighting against AIDS who

simultaneously question important taboos regarding sexuality, claimed as nonstandardized, and regarding death. The voice of the people is brought out through this case study, and deserves to be heard as a voice from a kind of 'underground', 'alternative', or 'non-politically correct' civil society. Needless to say that further research is needed on this topic.

\section{The NeEd For SeX EduCATION}

The purpose of a section of the 'Mercy Memorial Foundation' (Xingying jijinghui), the 'Center for Family Life and Sex Education' (Jiating shenghuo yu xingjiaoyu zhongxin), is to elaborate and develop sex education programmes in co-operation with two state bodies - the DoH operating as a funding agency, and the 'Bureau of Social Affairs' institutionally affiliated within the Ministry of Education (Jiaoyu bu shehui ju). The foundation favours international exchanges, particularly trans-Asian cooperation and is currently working on projects with the Hong Kong-based 'Sex Education Associates', with the international 'Asia Sex Education Committee', and with the Shanghai 'Chinese Association of Sexology' (Zhongguo xing xuehui), which now have representatives in every province of mainland China. Some associations provide information services since 1989.

Since the late 1980s, Prof. Yen (1989), professor of health education at National Taiwan Normal University, president of the 'Asian Federation for Sexology' (Yazhou xingxue huiyi), and executive director of the 'Mercy Memorial Foundation', has vigorously supported the introduction of sex education in schools on a national scale. His long-term, pioneering work has ineluctably shown the need for sex education to solve a number of social and health issues in a society facing rapid and drastic social changes, and the need for a better understanding of human sexual life at an individual level as well as at a societal level. To illustrate this, I will quote the summary of a paper, which he delivered at a 1988 conference. In this, he discussed the relevance, definition, objectives, and contents of sex education, and reviewed a number of essays related to sex education collected between 1977 and 1989. Based on the ideas about sex knowledge, attitudes, sexual behaviour, and sex education expressed in the materials, he had drawn a few concluding lines: 
- The lack of sexual knowledge was a common phenomenon

- The source of what knowledge there was came mainly from peers.

- There was a general support for sex education and a gradual acceptance of premarital sex, although the society still showed signs of conservatism towards sex.

233

- Data on premarital sex were analysed and compared in several essays.

- The emphasis on sex education designed for local students should be focused on knowledge about gendered relations, as well as the biological and psychological aspects of sexuality. Nowadays, research fellows affiliated with the 'Mercy Memorial Foundation' draw their results from both field studies and documentary research. On the basis of these manuals are compiled which are more in keeping with the times and educational videotapes. Personnel from the educational sector (professors, teachers, directors) are welcome to ask for information, training, and educational materials. Recent surveys were conducted among four groups of the population (parents, teachers, experts, students) using the KABP 'Knowledge, Attitude, Belief, and Practice' method. The results of these surveys are being used to realign the contents of sex education programmes. In September 1998, the foundation released the results of a recent survey on the sexual behaviours of young people. This survey reports on information channels about sex: for 34 per cent, sex knowledge comes primarily from books; for 17 per cent from school; for 13.3 per cent, from sexual partners; for 12.8 per cent, from friends or classmates; the last informative channel, the family context (parents), account for 7 per cent of young people. The results were widely available on a number of Internet websites. In 1998, sex education was still a new discipline in schools, and was being introduced into fields such as education, biology, psychology, and social work. A largescale national programme is difficult to implement in the face of the opposition from a certain number of teachers and parents. Sex education is designed for all levels from kindergarten to university. Since 1995, sex education has been included in the following university departments: social work, public health, psychology, and health education. It was already compulsory in health education programmes (guozhong: high school level) and exclusively female nursing training (gaozhong: senior high school level) of public schools. In universities, it was part of the compulsory self-defence classes (ziqiuke).

\section{CONCLUDING REMARKS}


Civil society in the Taiwanese pluralistic society as observed through the lens of social organizations is still in the process of maturing. Its emergence does not automatically generate structural changes allowing progressive voices to be heard. Moreover, social order could be strengthened and conservatism may be on the rise, seized on as a way for the people to face the drastic and rapid transformations challenging Taiwanese society. For instance, a rather conservative religious organization as the Buddhist Foundation (Ciji hui) is the most favoured social organization as both the amount of funds raised and high membership figures show.

These cautionary remarks are not intended to dispel a more encouraging view on the ongoing development of a civil society. A few progressive Chinese language publications are concerned with AIDS and gender-related topics. ${ }^{15}$ The publications and research of the 'Sex Center' at the Central University offer progressive views, as well as movies such as 'Meili Shaonian' and 'Bu zhi shi xiyan' directed by Mickey Chen. However, the readership of all these publications is still limited, and the existence of these works does not demonstrate that progressive voices are heard in society and have an impact on most social actors. Moreover, in her content analysis of AIDS campaign messages and news coverage, Hsu (1998) has shown that themes dealing with attitudes toward PWA/HIVs and their civil rights are almost inexistent constituting less than 2 per cent of the total.

I will recall also here the results of a 1997 poll showing high interest in volunteerism among young people (Wu 1997): 'Young people most commonly volunteer their time in social welfare services, community development programs, counselling for youngsters or adolescents, health care services and environmental protection programs, in that order. Up to $90 \%$ of the respondents hold a positive view of voluntary services, saying volunteerism can not only promote social harmony but also contribute to one's own growth or self satisfaction. Most local young people want the government and private enterprises to play a more active role in promoting voluntary services. Encouraged by the survey findings, the National Youth Commission will launch programs aimed at pooling the resources of the government and the private sector to create a clean living environment.'

Traditional values such as promoting social harmony, confronted by 'globalizing' values such as the rise of individualism account for the motivation of young people involved in volunteerism. Following widespread protests denouncing governmental inertia about environmental issues, these currently stand high on the political agenda, becoming a political stake in both local and national elections. Ecological and Buddhist groups, or one or the other, have increased the awareness of the population about environmental protection through campaigns, thus urging the government to take concrete measures. 
The activist movement against AIDS is embedded in a global context but its practices and claims are 'contextualized' and reinterpreted through local meanings as some aspects of the AIDS memorials and the AIDS campaign have shown. Finally, our case-study of the AIDS campaign has shown through the working methods of social organizations involved in

the fight against the disease, state policies, and the difficulties encountered in implementing sex education programmes that an epidemic threat such as the AIDS disease is a challenging social issue in a democratizing society.

\section{Notes}

. 1 The draft of this paper was presented at The 2000 North American Taiwan Studies Conference, June 16-19, Harvard University, Mass. Some parts of it have been revised from Micollier, E. 2000a.

. 2 Unfortunately I did not have the opportunity to work as a participant- observer with religious organizations as I had to select a few organizations to work with and I chose to focus on secular social organizations. It seems to me that these latter organizations were more significant in the analysis of the development of a civil society and of a pluralistic society in Taiwan. Indeed, as mentioned elsewhere in the paper, religious organisations were encouraged to blossom by the Nationalist government in contrast to secular social organizations, which develop during the 1980s accompanying the process of democratization.

. 3 Field research was carried out in 1997 (4 months) thanks to the support of the 'Centre for Chinese Studies', National Central Library, Taipei, and of the CNRS-SHS Dept, 'National Programme on AIDS', Paris.

. 4 Aristotle and most political theoreticians until the eighteenth century, include the State in the political community. In the nineteenth century, civil society is opposed to the State, an idea conceived by Hegel and systematized by the Marxists (Gramsci, 1930s), see Gresle F., Panoff M., Perrin, M., et P. Tripier (1990: 306).

. 5 Data from 'Taiwan Report: The Non-profit Sector in Taiwan: Current state, New Trends and Future Prospects' (1998). 
. 6 As in Japanese official figures, the categories 'foreigner/local' are the first reported distinction, cf. Buckley, S. (1997: 265).

. 7 The trend has been reversed this year following an official policy aimed to restrain foreign labour in sectors in which they are competing with local workers., cf. The Echoes of the ROC, Sept. 21, 2000: 2.

. 8 Patients are not reimbursed only when they ask for a very recently commercialized medication, which is not yet on the list approved by the DoH. On the National Health Insurance Scheme introduced in 1995, cf. 'National Health Insurance' Public Health in Taiwan (1997); Ku Yeun- Wen (1998).

9 See 'Control of Communicable Diseases' Public Health in Taiwan, 1997: 52-72.

. 10 The Echoes of the ROC, March 11, 1999. 236

. 11 This part is revised from Micollier, E. 2000b.

. 12 See Sontag, S. 1993; Farmer, P. 1992; in Japan, cf. Buckley, S. 1997; in Taiwan, Hsu et al.'s paper in this volume, in Taiwan and China, Micollier 1999.

- 13 I attended this ceremony (part of World AIDS Day activities) late afternoon on Dec. 29 of 1997 taking place in Taipei along the Yun-non River; the 'Hope workshop' was granted the authorization to organize it since 1994.

- 14 Although HIV/AIDS-related news reports may reinforce the process of stigmatization. For an overall analysis of these reports, and in particular in relation to the stigmatization of PWA/HIVs, see Hsu et al.'s paper in this volume.

. 15 Among them, see the daily paper 'Li-Bao', the weekly magazines 'POTS' and 'Stir', the journals 'The Isle Margin' and 'Awakening'.

\section{REFERENCES}

Brummelhuis H.T. and G. Herdt (eds) (1995) Culture and Sexual Risk. Anthropological Perspectives on AIDS. Amsterdam and Philadelphia: Gordon/Breach Ed.

Buckley, S. (1997) 'The Foreign Devil Returns: Packaging Sexual Practice and Risk in Contemporary Japan,' in: L. Manderson and M. Jolly (eds) Sites of Desire, Economies of Pleasure. Sexualities in Asia and the Pacific. Chicago and London: University of Chicago Press, pp. 262-91.

Cabestan, J.P. (1999) Le système politique de Taiwan. Paris: PUF, coll. 'Que sais-je?’ N. 
1809.

Chang H, Ho C., Shih An-Ti, Chien Ching-Shu and Tang Shao (eds) (1997) Taiwan aizibing beidan gushi. (Stories from Taiwan's AIDS Quilt). Taipei: Chinese Society of Preventive Medicine, bilingual Chinese- English, 24 pp.

De Vido, E.A. (2001) 'An Audience with Venerable Master Zheng Yan', The Taipei Ricci Bulletin, Taipei Ricci Institute, pp. 77-102.

Ethnologie française (1998) N. spécial 'SIDA: deuil, mémoire, nouveaux rituels,' Vol. XXVIII N. 1.

Farmer, P. (1992) AIDS and Accusation. Berkeley: University of California Press.

Fellous, M. (1998) 'Le Quilt: un mémorial vivant pour les morts du SIDA' Ethnologie française N. spécial 'SIDA: deuil, mémoire, nouveaux rituels' XXVIII(1), pp. 80-6.

Geoffroy, C. (1997) Le mouvement indépendantiste taiwanais. Paris: L’Harmattan.

Gresle F., M. Panoff M., M. Perrin M. and P. Tripier (1990) Dictionnaire des sciences humaines. Paris: Nathan.

Habermas, J. (1989) The Structural Transformation of the Public Sphere: An Inquiry into a Category of Bourgeois Society. Cambridge: MIT Press. Hsiao, Hsin Huang M. (1995) 'The Growing Asia Pacific Concern among Taiwan NGOs' in T. Yamamoto (ed.) Emerging Civil Society in the Asia Pacific Community. Tokyo, Japan Center for International Exchange, pp. 239-44.

Hsu, Cho-Yun (1994) 'Development of the State-Society Relationship in Early China' in: L. Vandermeersch (ed.) La société civile face à l'Etat dans les traditions chinoise, japonaise, coréenne et vietnamienne. Paris: EFEO, Etudes thématiques 3, pp. 1-16.

Hsu, Mei-Ling (1998) 'Issue Importance and Source Reliability of AIDS in Taiwan : A Comparison of the News and Campaign Agenda-Setting,' Paper presented at the annual meeting of the Health Communication Division, International Communication Association, Jerusalem, July.

Huang, P. (ed.) (1993) 'Symposium 'Public sphere/Civil society' in China? Paradigmatic 
issues in Chinese studies,' Modern China 19(2), pp. 107-216.

$\mathrm{Ku}$, Yeun-Wen (1998) 'Can we afford it? The development of National Health Insurance in Taiwan,' in R. Goodman, G. White, H.J. Kwon (eds) The East Asian Welfare ModelWelfare Orientalism and the State. London: Routledge, pp. 119-38.

Kwok, D.W.Y. (1994) 'Moral Community and Civil Society in China: Enigmas viewed from the Traditions of Protest and Political Advice,' in: L. Vandermeersch (ed.) La société civile face à l'Etat dans les traditions chinoise, japonaise, coréenne et vietnamienne. Paris: EFEO, Etudes thématiques 3, pp. 17-28.

Laliberté, A. (1998) 'Tzu Chi and Buddhist Revival in Taiwan. Rise of a new conservatism?' China Perspectives 19, pp. 44-50.

Lu, Zxy-Yann Jane (1990) Ill fate: Women's illnesses experiences in the pluralistic health care system of Taiwan. Ph. D. dissertation, University of Michigan.

Ma, Shu-Yun (1994) 'The Chinese discourse on civil society,' The China Quarterly 137, pp.180-93.

Micollier, E. (1999) 'L'Autre : porteur originel et/ou vecteur privilégié du VIH/SIDA (Chine populaire-Taiwan),' in: C. Fay (ed.) 'Le sida des autres : constructions locales et internationales de la maladie,' Autrepart (Cahiers des sciences humaines), IRD-L'Aube 12 , pp. 73-86.

Micollier, E. (2000a) 'Emergence de la société civile à Taiwan: vers une gestion collective des problèmes de santé,' in: C. Chaîgne, C. Paix and C. Zheng (eds) Taiwan. Enquête sur une identité. Paris, Karthala, pp. 309-31

238

Micollier, E. (2000b) 'Analyse de la campagne de prévention à Taiwan,' dans M.E.Blanc, L. Husson and E. Micollier (eds) Sociétés asiatiques face au SIDA. Paris, L'Harmattan, coll. «recherches asiatiques», pp. 229-52.

Public Health in Taiwan. Taipei: DoH, Executive Yuan 1997.

Sontag, S. (1993) La maladie comme métaphore. Le sida et ses métaphores. Paris: C. Bourgois. 
'Taiwan Report: The Non-profit Sector in Taiwan. Current state, New Trends and Future Prospects' (1998) Background Paper delivered at the International Conference on Philanthropy, Asia Pacific Philanthropy Consortium, Bangkok, January.

Ting Chih-Yin and Shing-Jer Twu (1997) 'Aizibing fengxian yishi de linchuang fanghu ji zhaohu yiyuan,' (AIDS Risk, Physicians Clinical Precautions and Willingness to Treat AIDS Patients) Zhonghua weizhi (China Journal of Public Health, Taipei) 16(3), pp. 23143.

Vermander, B. (1995) 'Religions in Taiwan today,' China News Analysis July 1, N. 15389, pp. 1-15.

Wachman, A.M. (1994) Taiwan: National Identity and Democratization. New York: M.E. Sharpe.

Wu, S. (1997) 'Poll: Interest in volunteerism high', The China Post 12 Sept., p. 18.

Yuan H.S., Pan J.Y. and J.W. Chen (1994) 'Wu zhuanji zhixiao gaonianji husheng dui aizibing zhishi taitu ji huli yiyuan zhi tantao,' (AIDS Related Knowledge, Attitudes and Willingness in Caring for Patients Among Senior Nursing Students from a 5-Year Junior College and Vocational Schools), Huli zazhi (Nursing Journal, Taipei) 41(3), pp. 41- 51.

Zhi Xiao, Zhang Wei, and Ai Mo (1997) Tongzhi zhi zhenbian shu (The Book of Silent Love). Taipei: Chinese Society of Preventive Medicine, 45 pp. 